\title{
SITE SUITABILITY ANALYSIS FOR URBAN DEVELOPMENT USING GIS BASE MULTICRITERIA EVALUATION TECHNIQUE IN NAVI MUMBAI, MAHARASHTRA, INDIA
}

\author{
Sandip Patil \\ Department of Civil Engineering
}

M. E Research Scholar, Pillai HOC College of Engineering and Technology

Pillai HOC College of Engineering and Technology, Rasayani, Raigad, Maharashtra, India,

\section{Manisha Jamgade}

Department of Civil Engineering

Assistant Professor, Pillai HOC College of Engineering and Technology

Pillai HOC College of Engineering and Technology, Rasayani, Raigad, Maharashtra, India

\begin{abstract}
During the planning of urban area economic and social factor are consider planning. Future growth of economic is depend on infra-structure development and utility. Finding appropriate site for development in hilly area facing the problem and difficulty for planning and implementation. Appropriate site analysis is providing sure skeleton for conducting various development, particularly in the rising and falling ground associated with the hills with helping of geographic information system and multicriteria evaluation technique to find appropriate site for development in Navi Mumbai, Maharashtra, India. In this process of site selection some thematic maps layers are prepared using ArcGIS software. Site selection Standards use for analysis such as slope, land use /land cover map, road proximity, digital elevation, flood map and rainfall map. Category weight is given according to importance and maps were convert into raster. Weights overlay in give all importance to each category then process to preparation suitable site selection map for development. Using all maps prepare suitable site selection map is created. It is essential for designing spatial analysis map for taking any decision relating to development in which remote sensing facilitate important role. This study is useful for planner, public and other agency for planning project and implementations in area.
\end{abstract}

Keywords: Site suitability, GIS, Multicriteria evaluation (MCE), Pairwise comparison matrix, Analytical hierarchy process 
Cite this Article: Sandip Patil and Manisha Jamgade, Site Suitability Analysis for Urban Development using Gis Base Multicriteria Evaluation Technique in Navi Mumbai, Maharashtra, India International Journal of Advanced Research in Engineering and Technology, 10(1), 2019, pp 55-69.

http://iaeme.com/Home/issue/IJARET?Volume=10\&Issue $=1$

\section{INTRODUCTION}

Land use and land cover (LULC) study is the important aspect to manage natural resources. This is also used to realize the effect of manmade activities on the surrounding environment. One of the main descriptions of the LULC change of integrity might be the pace rapid urbanization is rapidly growing in the area. In developing the city and new construction resident and society living large number of populations in the city in 19 and 20 centuries. The growth in urban are is depend on the amound of people area moving from rural to urban area for of economic growth and better life style (Davis, 1955).

Urban area development and shifting of people from village to city area of a global issue. Many small spaces change quick grow and alter which population mega town and land alteration (Hauser et al., 1982).

Reliable and accurate land assessment is, therefore, necessary to the choice-making approaches involved with developing land use regulations which can help sustainable rural development. Satisfying demand and supply of agricultural food and product are completed by own production in developing countries and land assessment techniques are necessary to develop for a different type of agriculture land suitable for different type of production (Elaalem et al. 2010).

Quite often, especially in semi-arid regions, the limited availability of agricultural land is a critical factor. This increased stress on the available land resources may end up in land degradation (Elaalem et al. 2011).

GIS base Multicriteria evaluation techniques is easy which can be used in various suitability categories for any study area. It provides a complete and satisfactory database available for suitable land for development work and it help to solve any problem regarding development (Manish Kumar et.al 2012). Site suitability is a method of understanding site importance and quality factor and this factor show location for a particular activity. Detail investigation of natural resource and development that describe an area and include mapping techniques and GIS helps in process show different planning objectives (Santosh Kumar et.al, 2014).

It is the practice of individuals, institution and organization to find out suitable site selection such as school bus, airport and infrastructure. For better result find out a solution to the problem. Remodelling is the slight chance for setting criteria to improve for analysis and presentation (Ian Heywood, et al., 2006).

In the process identification of the suitable site selection to meet specific criteria. For the GIS based analysis is reduced time and effort otherwise search manually it takes too much time for the process. Finding new site for urban development become more challenging for speedily growing real estate market and transformation of land cost and environment rules. The result of site suitable analysis process shows the appropriate area for consider of placement of a less desirable area. A scoring and weight system will apply to completely different part appropriate to measure the general suitability for the particular urban user (Thurstone 1927).

In this site suitability analysis method use of AHP and GIS systems are used for finding suitable site for the urban growth within the study area. Ranking of this factor accomplished by implement by AHP for getting improved methodology and decision making for the creation of 
maps. In this study flood map use for getting high flood area information for better decisionmaking selection of area. Additionally, this study shows unsuitable area for urban growth.

\section{PROBLEM STATEMENT}

\subsection{Problem Statement}

Manual \& long-term processes: Manual process is one of the long-term processes to survey or analyse site suitability analysis process. Flat land surface area is easy for analysis, but in more of complication occur or facing in difficulty. You can survey a small area however it is complicated to cover a large geographical area.

Time-Consuming processes: Manual analysis always takes a long time period to survey the area for site suitability. The manual process took lots of time to find out which land surface is flat, which region is come under friendly to the environment region, which region come under river and pond, mountain region etc.

Economical Problem: Large amount of project cost is unnecessarily wasted for analysis of land surface tangled up in this project. Lake of technical aspects results in the process time intensive and complex.

\subsection{Solution to the Problem}

Solution to the Manual and long-term process: Automated process for analysis of the land surface area. Almost any surface field including flat, mountain and water bodies could be analyzed easily using ArcGIS.

Solution for time-consuming process: in the short period and rapid investigation in the hilly region or any area is possible using GIS.

Solution to Economical Problem: For the analysis of any area spending hug amount for suitable land analysis but using GIS as tool cost is reduced. software program is one-time investment in the project instead of spending extra cost.

\section{STUDY AREA}

Navi Mumbai is located in India, Maharashtra state, Asia continent. Latitude coordinate is the latitude of $19.077065^{\circ} \mathrm{N}$, and longitude is $72.998993^{\circ} \mathrm{E}$ and elevation of height is 14 meters above sea level. Temperature changes from $22^{\circ} \mathrm{C}$ to $36^{\circ} \mathrm{C}$. Winter temperature range is between $17^{\circ} \mathrm{C}$ to $20^{\circ} \mathrm{C}$ and summer range up to $36^{\circ} \mathrm{C}$ to $41^{\circ} \mathrm{C}$. The study area of Navi Mumbai is 344 $\mathrm{km}^{2}$ and this area is split into 14 nodes it divided into different sectors. Location of study area maps are show in figure 1 . 

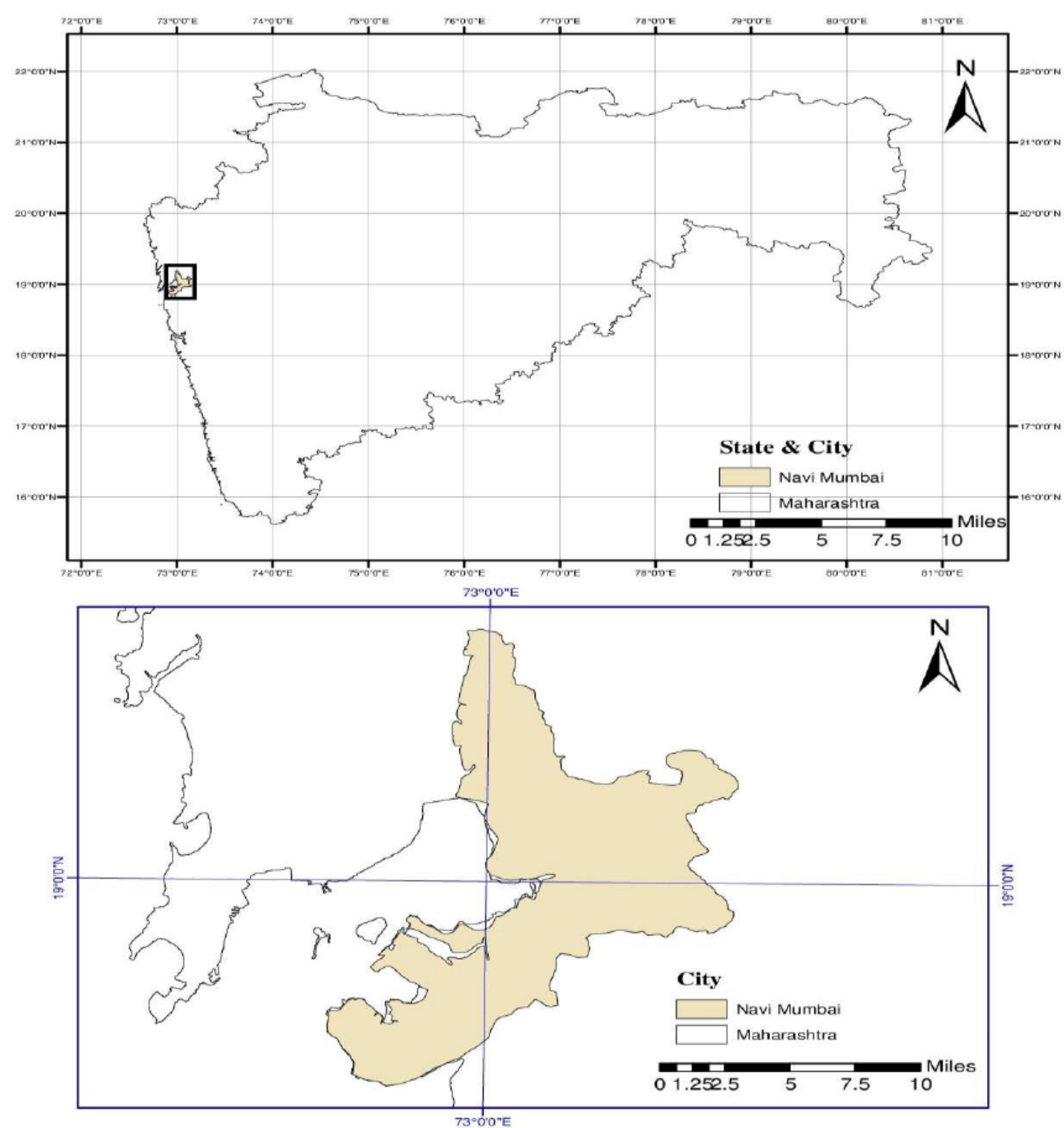

Figure 1 Study Area Location Map

\section{METHOD AND DATA COLLECTION}

\subsection{Data Collection}

Site suitability analysis needs a different type of thematic layer which are created with the help of toposheet scale 1:50,000. Satellite images and digital elevation data (DEM) is download from United State Geological Survey (USGS) this site and DEM is a process in ArcGIS for making slope map. For generating road layer map, data is taken from the open street map (OSM) this map is converted in to shapefile and export to ArcGIS. Download rainfall map is getting from Climatic Research Unit website. For download, rainfall map is getting from Climatic Research Unit and All data is converting from georeferenced in UTM zone 43 (WGS 84). 
Site Suitability Analysis for Urban Development using Gis Base Multicriteria Evaluation Technique in Navi Mumbai, Maharashtra, India

Table 1 Software and Data Source

\begin{tabular}{|c|c|c|}
\hline \multirow{2}{*}{ Sr No } & \multicolumn{2}{|c|}{ Software and Data Source } \\
\cline { 2 - 3 } & Type of Data & Source \\
\hline 1 & Digital Elevation Model (DEM) & $\begin{array}{c}\text { United States Geological Survey } \\
\text { (USGS) }\end{array}$ \\
\hline 2 & Rainfall Data & Climatic Research Unit \\
\hline 3 & Satellite Data & United States Geological Survey \\
\hline 4 & Software use & ArcGIS, ERDAS, QGIS. \\
\hline
\end{tabular}

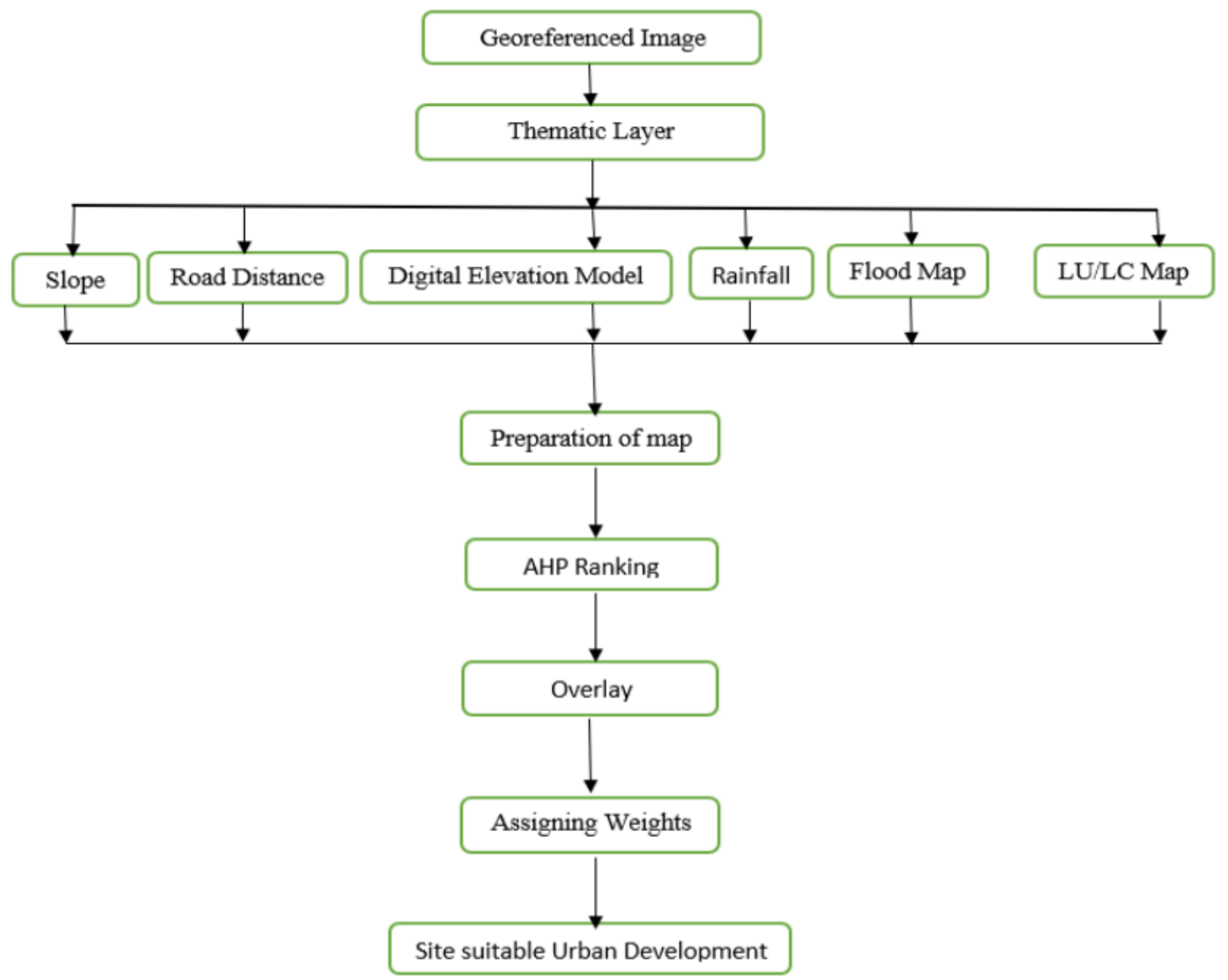

Figure 2 Flow Chart

\section{RESULTS AND DISCUSSION}

\subsection{Parameters for Suitability Development Assessment}

Different type aspects study in suitability analysis such as social economic and many factors are affecting the land use suitability.

Generally, social-economic factors are considered for use in spatial planning. In this study selected factors are not compulsive and only physic process parameter chosen, due to the aim is to work on perform physical geographical factors in planning. The objective is finding the 
appropriate site in the study area using a combination with physical and geographical features use. Use of six parameters in this study slope, rainfall, elevation, flood map, road distance, and LU/LC map. Selection of suitable parameter and determination of the classes number base on literature review and discussion with researchers.

\subsection{Suitability Scoring/Ranking and Development of Pairwise Comparison Matrix:}

For suitability analysis, it is crucial to provide some score to every associated with the criteria as per their suitability for urban development.

For achive specific objectives using satty's nine-point allowance scale in the pairwise comparison matrix. This nine-point comparison is obtained from Table 2. These pairwise comparisons are taken as input and relative weights are produced as an output.

\subsection{Computation of the Criterion Weights:}

Later the formation of the pairwise contrast matrix, computation regarding the criterion weights is clearly completed. The computation includes the following operations:

First calculate total in individual column of pairwise comparison matrix table and then second step estimate division of each and each aspect into the matrix by its column total. Final step calculation of average of elements in each row when it comes to the normalized matrix, for example, dividing the sum of normalized scores of each and every row because of the number of criteria

An evaluation is provided by these averages related with comparative weights of this criterion being compared (Malczewski 1999).

It ought to be detected that for eliminating bias thought standards weighting the consistency ratio (CR) was used.

Table 2 Nine-Point Weighting Scale for Pairwise Comparison, Saaty (1980).

\begin{tabular}{|c|c|c|}
\hline $\begin{array}{c}\text { Sr. } \\
\text { No }\end{array}$ & Description & Suitability class \\
\hline 1 & Equal importance & Lowest suitability \\
\hline 2 & $\begin{array}{c}\text { Equal to moderate } \\
\text { importance }\end{array}$ & $\begin{array}{c}\text { Very low } \\
\text { suitability }\end{array}$ \\
\hline 3 & Moderate importance & Low suitability \\
\hline 4 & $\begin{array}{c}\text { Moderate to strong } \\
\text { importance }\end{array}$ & $\begin{array}{c}\text { Moderately low } \\
\text { suitability }\end{array}$ \\
\hline 5 & Strong importance & $\begin{array}{c}\text { Moderate } \\
\text { suitability }\end{array}$ \\
\hline 6 & $\begin{array}{c}\text { Strong to very strong } \\
\text { importance }\end{array}$ & $\begin{array}{c}\text { Moderate-high } \\
\text { suitability }\end{array}$ \\
\hline 7 & Very strong importance & High suitability \\
\hline 8 & $\begin{array}{c}\text { Very to extremely strong } \\
\text { importance }\end{array}$ & $\begin{array}{c}\text { Very high } \\
\text { suitability }\end{array}$ \\
\hline 9 & Extremely importance & Highest suitability \\
\hline
\end{tabular}


Table Source: Saaty (1980)

Calculation of the consistency ratio (CR) is the measurement purpose validation and measure accuracy random judgment. The AHP is deals with primarily because which will make balance comparison exactly like thinking people would not have the basic commonsense capability to often to be unchanging (Saaty 1994).

For analysis of site suitability use standards six-layer and all mention in methodology followed by figure 2 . In the suitability site analysis for urban growth necessary to give ranking each criterion used for weights output and comparison matrix (Table 5).

In Comparison of pairwise calculation process sum of all value of element column divided each parameter. Estimate the average of a single row of matrix criteria weight and calculate consistency vector for estimate lambda $(\lambda)$ value. For calculation of $(n)$ in a random index value of lambda is consider in equal or less than of order matrix. According to $\lambda$-n can be considered as a way of calculating the total of inconsistency. The degree of in consistency can evaluation as a flowing formula.

$$
\mathrm{CI}=(\lambda-n) /(n-1)
$$

For calculation of CI index value of lambda consistency vector average and $n$ value is taken from order matrix for using equation 1.

For the calculate of CI need to calculate the value of CR and random index (RI) value is taken from Table 2 as shown in equation 2.

$$
\mathrm{CR}=\mathrm{CI} / \mathrm{RI}
$$

The random index is chosen from pairwise comparison matrix value of lambda for consider from appropriate 1-10 obtain by random index using a sample size of 500 (Saaty2000). Table 3 shows the random index (R.I).

Table 3 Random Index

\begin{tabular}{|c|c|c|c|c|c|c|c|c|c|c|}
\hline $\begin{array}{c}\text { Order } \\
\text { matrix }\end{array}$ & 1 & 2 & 3 & 4 & 5 & 6 & 7 & 8 & 9 & 10 \\
\hline R. I & 0 & 0 & 0.58 & 0.9 & 1.12 & 1.24 & 1.32 & 1.41 & 1.45 & 1.49 \\
\hline
\end{tabular}

If the calculated CR value is less than 0.1 then is correct and if it is greater than or equal 0.1 then it is wrong which represents that calculated consistency ratio show inconsistent judgment. In later case, all the value are reconsider in a pairwise comparison matrix.

Various kinds of maps are converted in a raster data format for better calculation (Chang 2006). Combined all maps and final suitability map after reclassifying all map integrated into ArcGIS and assign a weight for final output.

Site suitability analysis for urban development effective criteria is given individual importance. Slope is most important factor for construction work selection suitable site in hilly regions.

The steep slope is a disadvantage for construction and is limiting most floor area contributes to erosion throughout construction and Steep increase the value of the development. For the construction suitable slope consider less than 10 degrees (Rawat 2010).

In this analysis process, land use and cover map are divided into a various category such as forest land, open land, agricultural land, constructed area, and waterbody.

The road is one of the among foremost necessary factor to find site suitability in the area for a better transportation facility. Time to time delivery needs a better root for transporting 
materials. So, it is better to select a suitable site find easy road access for this purpose creating distance map from the road.

In addition to various social and economic aspects of the city, safety and security from flood and totally different natural hazards are also necessary aspects of planning and the development. In the case of Navi Mumbai town, correct care ought to be thought-about for flood zones that are existing on central north-south areas. New construction comes in these zones ought to be prevented based on the intensity of the flood zone.

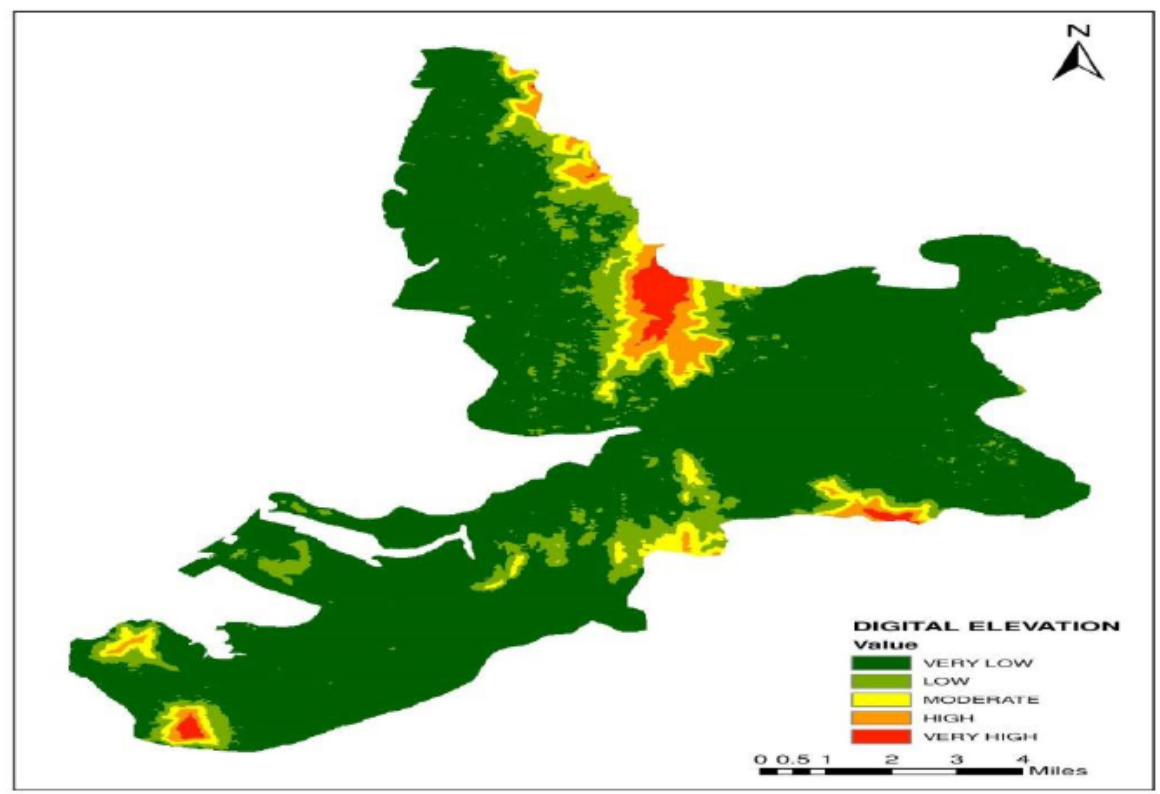

Figure 3a Digital Elevation Map

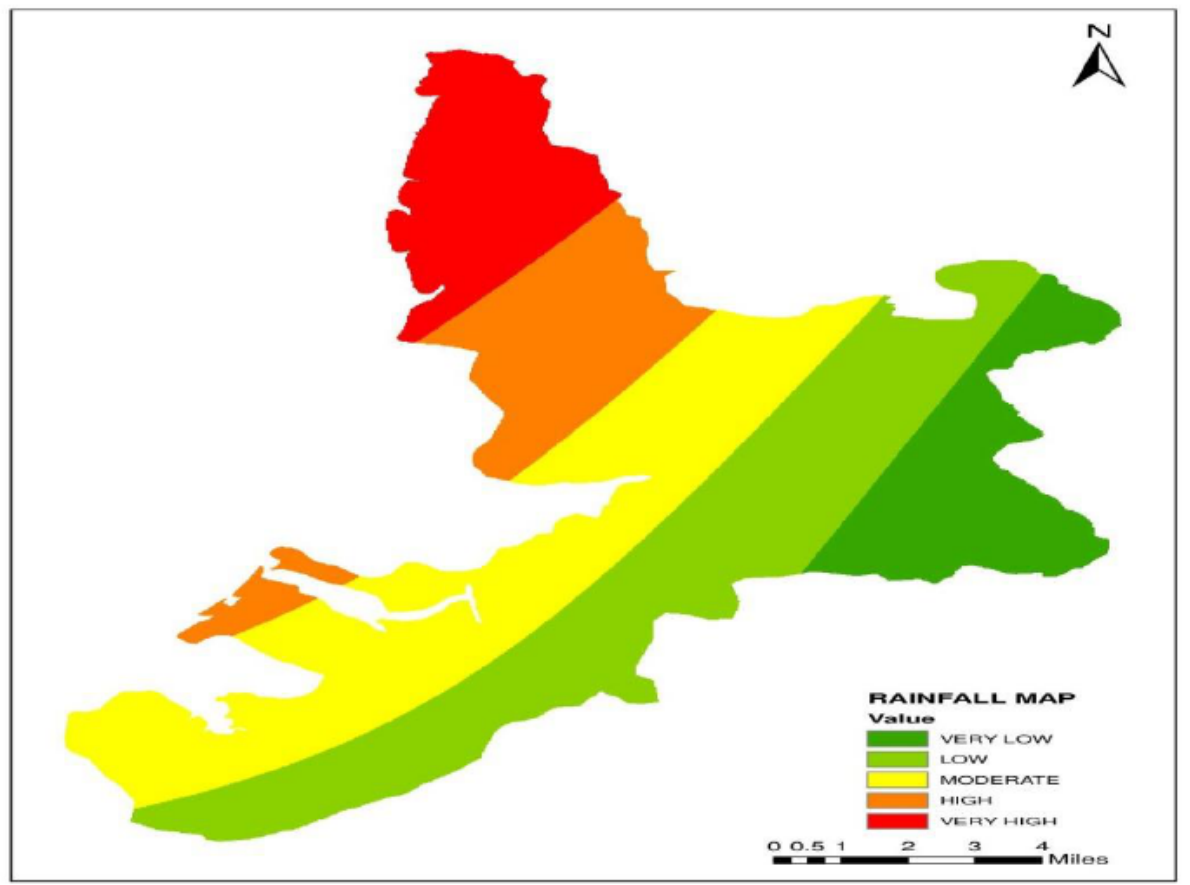

Figure 3b Rainfall Map 
Site Suitability Analysis for Urban Development using Gis Base Multicriteria Evaluation Technique in Navi Mumbai, Maharashtra, India

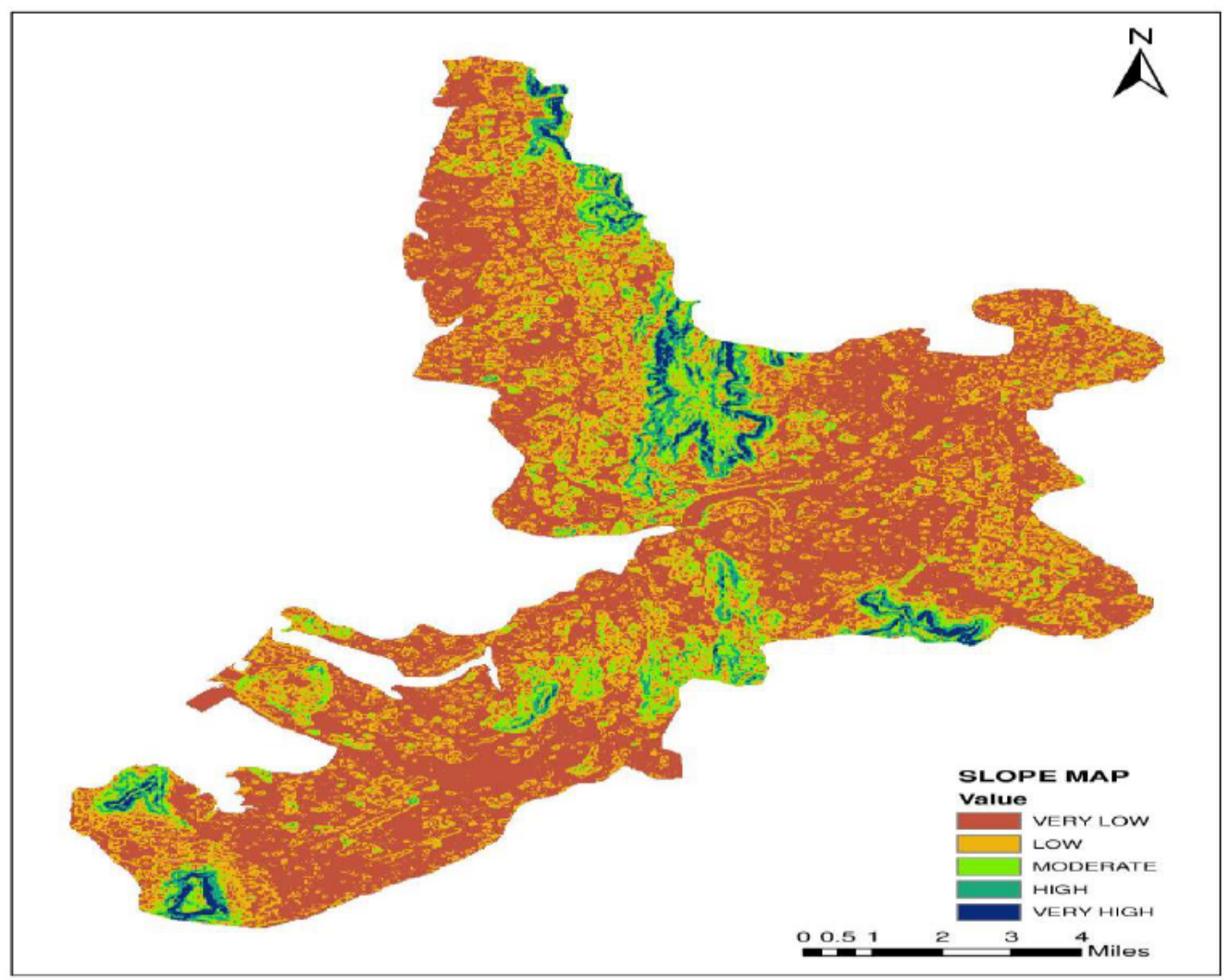

Figure 3c Slope Map

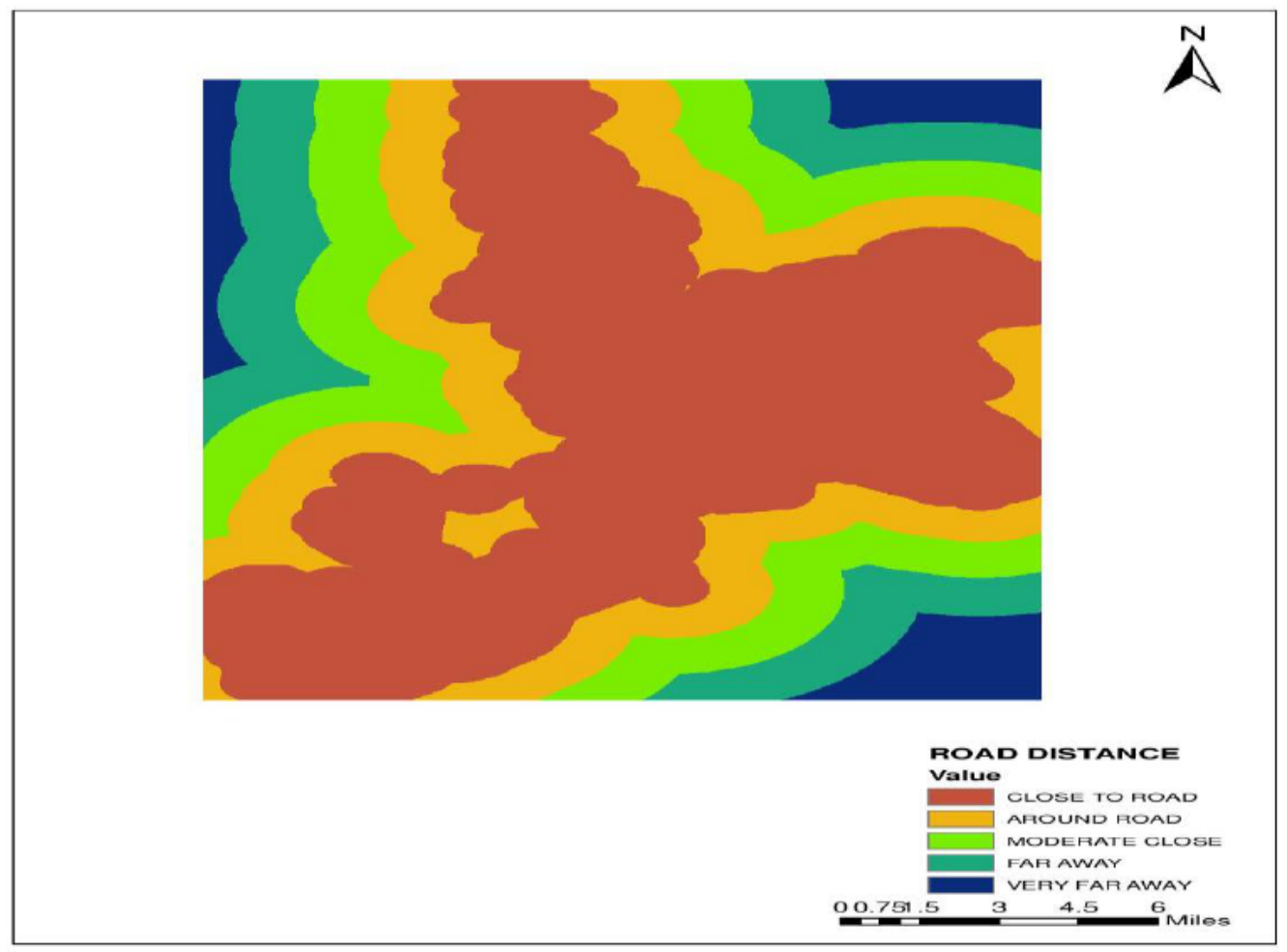

Figure 3d Road Distance Map 


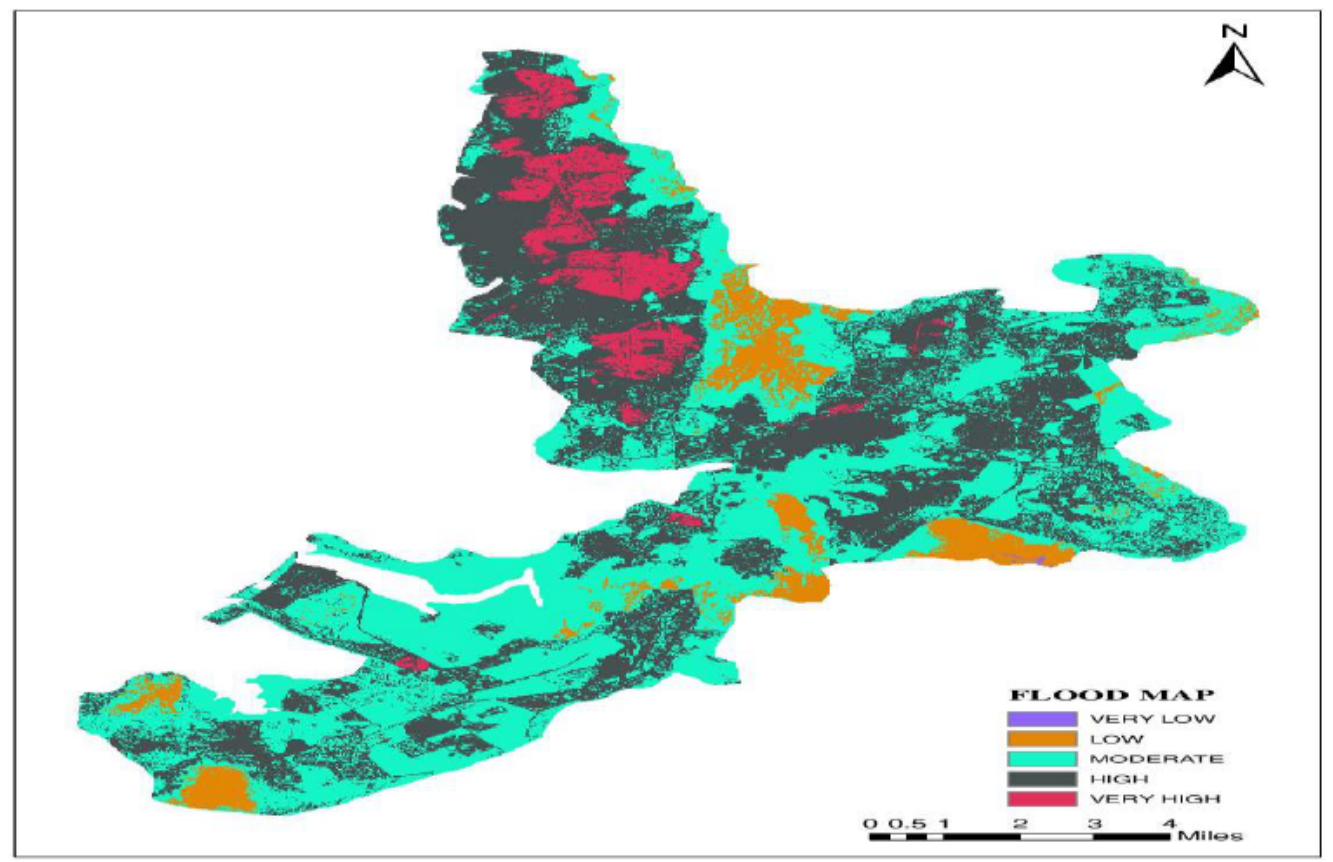

Figure 3e Flood Map

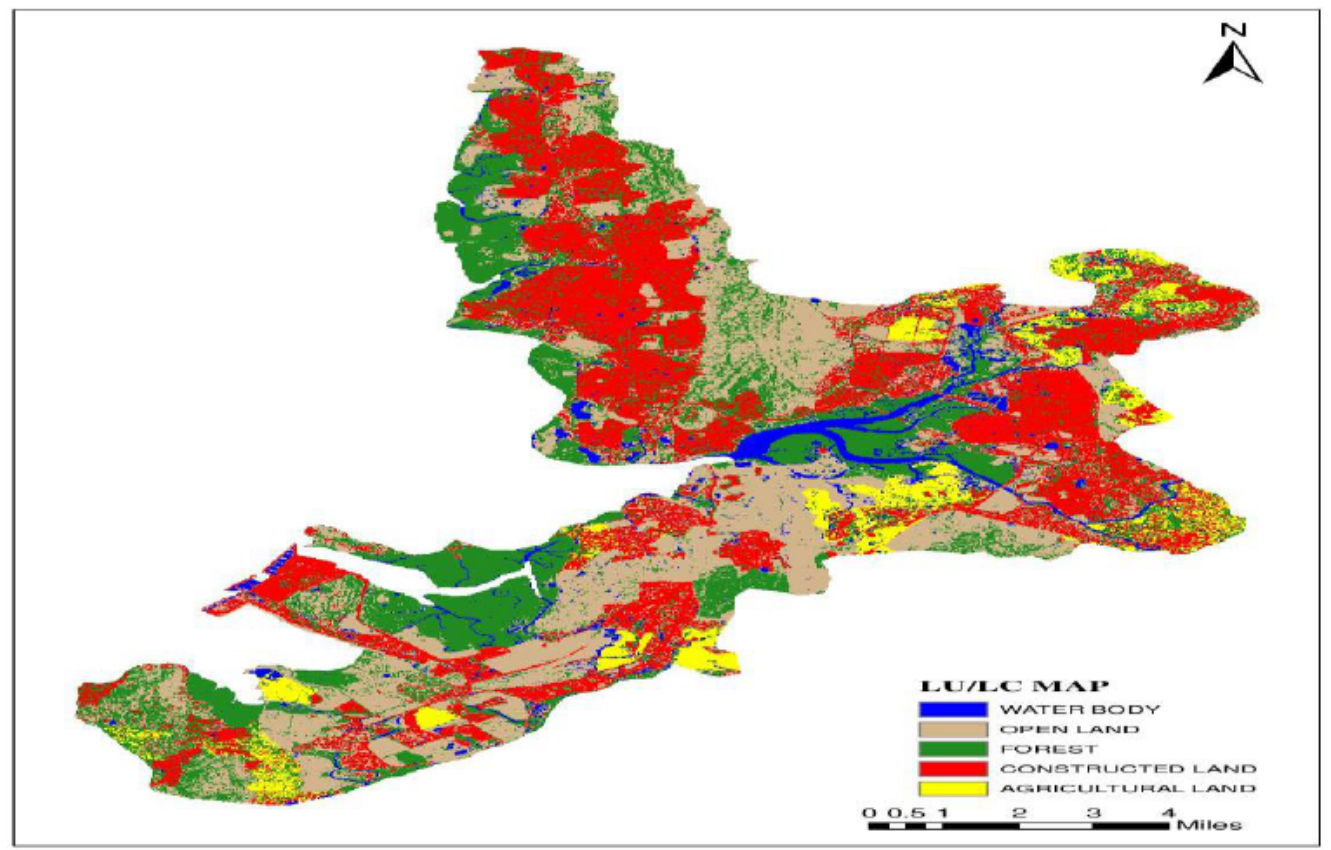

Figure 3f Land Use/ Land Cover Map

Figure 3. a) Slope Map, b) Road Distance, c) Digital Elevation, d) Rainfall Map, e) Flood Map, f)LU/LC Map

Scoring/Ranking Criteria: The scoring used for suitability in this study each criteria map and their category at 9-point weighting scale are given in Table 3. Using available criteria Pairwise Comparison Matrix and Weighing of Criteria are created in (Table 4) 
Site Suitability Analysis for Urban Development using Gis Base Multicriteria Evaluation Technique in Navi Mumbai, Maharashtra, India

Table 4 Ranking of Criteria

\begin{tabular}{|c|c|c|c|c|c|c|c|}
\hline Score & Importance & $\begin{array}{c}\text { Slope } \\
\text { (Degree) }\end{array}$ & $\begin{array}{c}\text { Road } \\
\text { Dist. } \\
\text { (Meter } \\
\text { ) }\end{array}$ & $\begin{array}{c}\text { DEM } \\
\text { (Meter } \\
\text { ) }\end{array}$ & $\begin{array}{c}\text { Rainfall } \\
\text { (mm) }\end{array}$ & $\begin{array}{c}\text { Flood } \\
\text { Map } \\
\text { (area) }\end{array}$ & $\begin{array}{c}\text { LU/LC(Cla } \\
\text { ss) }\end{array}$ \\
\hline 5 & Very High & $\begin{array}{l}24.72- \\
52.10\end{array}$ & $\begin{array}{l}7541- \\
12821\end{array}$ & $\begin{array}{l}237- \\
405\end{array}$ & $\begin{array}{l}2310- \\
2389\end{array}$ & 17.76 & $\begin{array}{l}\text { Agricultural } \\
\text { land }\end{array}$ \\
\hline 4 & High & $\begin{array}{l}14.50- \\
24.72\end{array}$ & $\begin{array}{c}5178- \\
7541\end{array}$ & $\begin{array}{l}155- \\
237\end{array}$ & $\begin{array}{l}2231- \\
2310\end{array}$ & 137.22 & $\begin{array}{c}\text { Constructer } \\
\text { land }\end{array}$ \\
\hline 3 & Moderate & $\begin{array}{l}7.151- \\
14.50\end{array}$ & $\begin{array}{l}3016- \\
5178\end{array}$ & $87-155$ & $\begin{array}{l}2152- \\
2231\end{array}$ & 160.93 & Forest land \\
\hline 2 & Low & $\begin{array}{l}2.451- \\
7.151\end{array}$ & $\begin{array}{l}1106- \\
3016\end{array}$ & $34-87$ & $\begin{array}{l}2073- \\
2152\end{array}$ & 23.31 & Open land \\
\hline 1 & Very Low & $0-2.451$ & $0-1106$ & $0-34$ & $\begin{array}{l}1994- \\
2073\end{array}$ & 0.126 & Water body \\
\hline
\end{tabular}

Table 5 Pairwise Comparison Matrix

\begin{tabular}{|c|c|c|c|c|c|c|}
\hline & Slope & $\begin{array}{c}\text { Road } \\
\text { Proximity }\end{array}$ & DEM & Rainfall & $\begin{array}{c}\text { Flood } \\
\text { Map }\end{array}$ & LU/LC \\
\hline Slope & 1 & 2 & 4 & 5 & 7 & 9 \\
\hline $\begin{array}{c}\text { Road } \\
\text { Proximity }\end{array}$ & 0.5 & 1 & 2 & 4 & 5 & 7 \\
\hline DEM & 0.25 & 0.5 & 1 & 2 & 4 & 5 \\
\hline Rainfall & 0.2 & 0.25 & 0.5 & 1 & 2 & 4 \\
\hline Flood Map & 0.14 & 0.2 & 0.25 & 0.5 & 1 & 2 \\
\hline LU/LC & 0.11 & 0.14 & 0.2 & 0.25 & 0.5 & 1 \\
\hline Total & 2.20 & 4.09 & 7.95 & 12.75 & 19.5 & 28 \\
\hline
\end{tabular}


Sandip Patil and Manisha Jamgade

Table 6 Consistency Vector

\begin{tabular}{|c|c|c|c|c|c|c|c|}
\hline & Slope & $\begin{array}{c}\text { Road } \\
\text { Proximity }\end{array}$ & DEM & Rainfall & $\begin{array}{c}\text { Flood } \\
\text { Map }\end{array}$ & LU/LC & $\begin{array}{c}\text { Total } \\
\text { Weight }\end{array}$ \\
\hline Slope & 0.45 & 0.48 & 0.50 & 0.39 & 0.35 & 0.32 & 0.42 \\
\hline $\begin{array}{c}\text { Road } \\
\text { Proximity }\end{array}$ & 0.24 & 0.24 & 0.25 & 0.31 & 0.25 & 0.25 & 0.26 \\
\hline DEM & 0.11 & 0.12 & 0.12 & 0.15 & 0.20 & 0.2 & 0.15 \\
\hline Rainfall & 0.09 & 0.06 & 0.06 & 0.07 & 0.10 & 0.14 & 0.08 \\
\hline Flood Map & 0.06 & 0.04 & 0.03 & 0.03 & 0.05 & 0.07 & 0.05 \\
\hline LU/LC & 0.05 & 0.03 & 0.02 & 0.01 & 0.02 & 0.03 & 0.03 \\
\hline
\end{tabular}

Table 7 Calculation of Consistency Vector

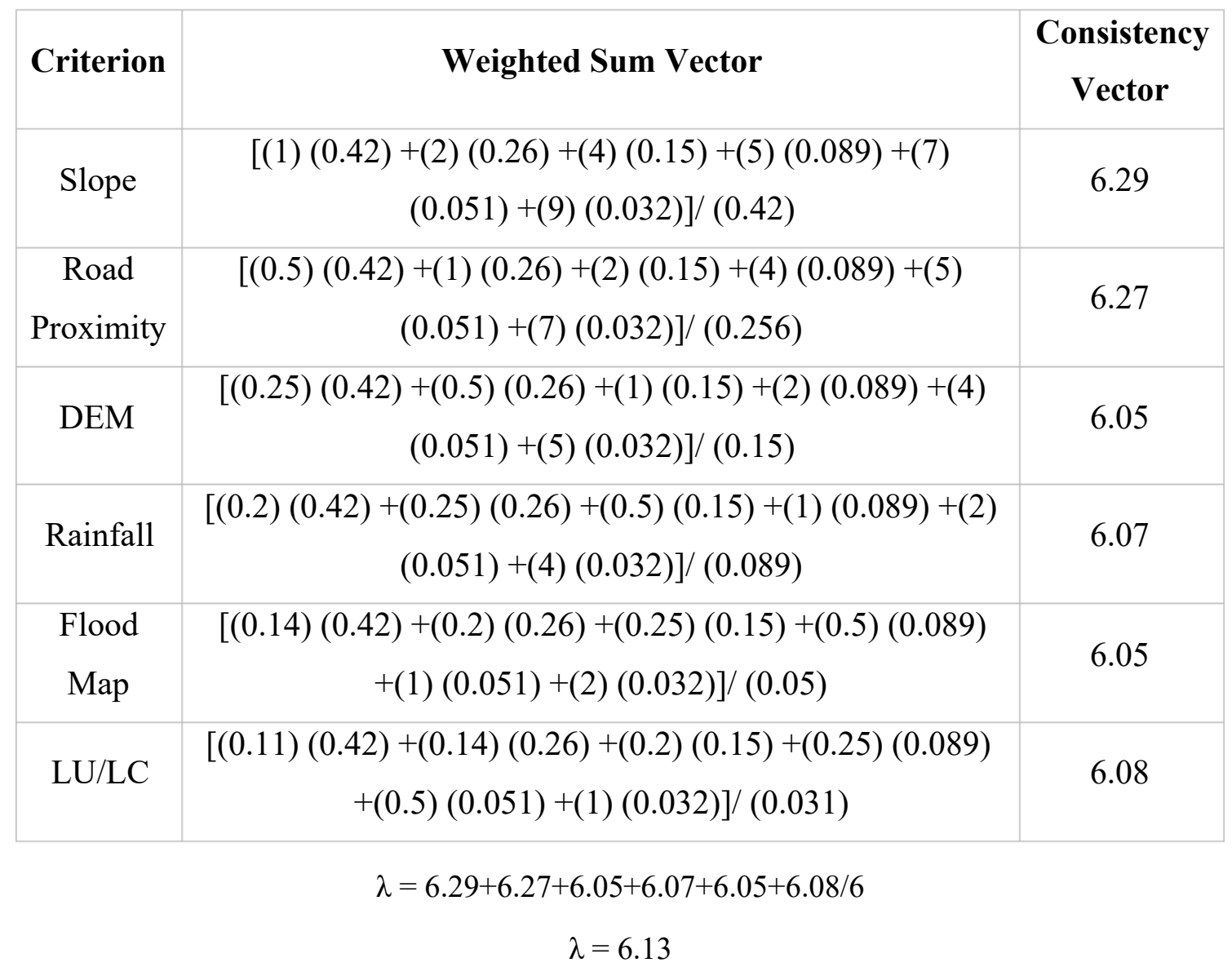

For calculation the consistent vector use the formula for single category for example slope Pairwise Comparison Matrix row multiply by total weight Colum and divided by category Weight. weighted sum vector and consistency vector calculation value are shown in the Table number 7 .

Condition 1: Consistency ratio value ought to be the same or larger than the number of criteria into consideration. The consistency ratio value calculated above if satisfies this condition.

Calculation of consistency index (CI) 
Site Suitability Analysis for Urban Development using Gis Base Multicriteria Evaluation Technique in Navi Mumbai, Maharashtra, India

$$
\begin{gathered}
\lambda=6.13, \mathrm{n}=6 . \\
\mathrm{CI}=(\lambda-\mathrm{n}) /(\mathrm{n}-1)=[(6.13-6) /(6-1)] \\
\mathrm{CI}=0.026
\end{gathered}
$$

Calculation of consistency ratio (CR)

$\mathrm{CR}=\mathrm{CI} / \mathrm{RI}=0.026 / 1.24$

$\mathrm{CR}=0.020$

Condition 2: In this consistency ratio $(C R)$ result the value $C R$ is $(00.020)<0.10$. since the result is show a sensible level of consistency in the pairwise comparisons. Therefor result is satisfying all value get from equation 2 and condition.

The map used from all six categories convert additional format to raster format, so every pixel a score is calculated (Jain and subbaiah 2007). For to get final suitability analysis overlaid all map decide by different category.

The final site suitability map (Fig. 3) show the study area was separated into six different appropriate categories. The area under very low, low, moderate, high and very high lands stand at $38.83 \mathrm{~km} 2,2.24 \mathrm{~km} 2,127.62 \mathrm{~km} 2,129.34 \mathrm{~km} 2$ and $41.29 \mathrm{~km} 2$ respectively (Table 8). In $49.48 \%$ of the total area come under very low, low and moderate suitable areas. Remain of all is $50.52 \%$ of land comes under high and very high suitable types.

Table 8 Area Under Different Suitability Categories

\begin{tabular}{|c|c|c|}
\hline Suitability categories & Area $\left.\mathbf{( k m}^{\mathbf{2}}\right)$ & Area (\%) \\
\hline Very low & 38.83 & 11.3 \\
\hline low & 2.24 & 0.66 \\
\hline Moderate & 127.62 & 37.52 \\
\hline High & 129.34 & 38.26 \\
\hline Very High & 41.29 & 12.26 \\
\hline
\end{tabular}


Sandip Patil and Manisha Jamgade

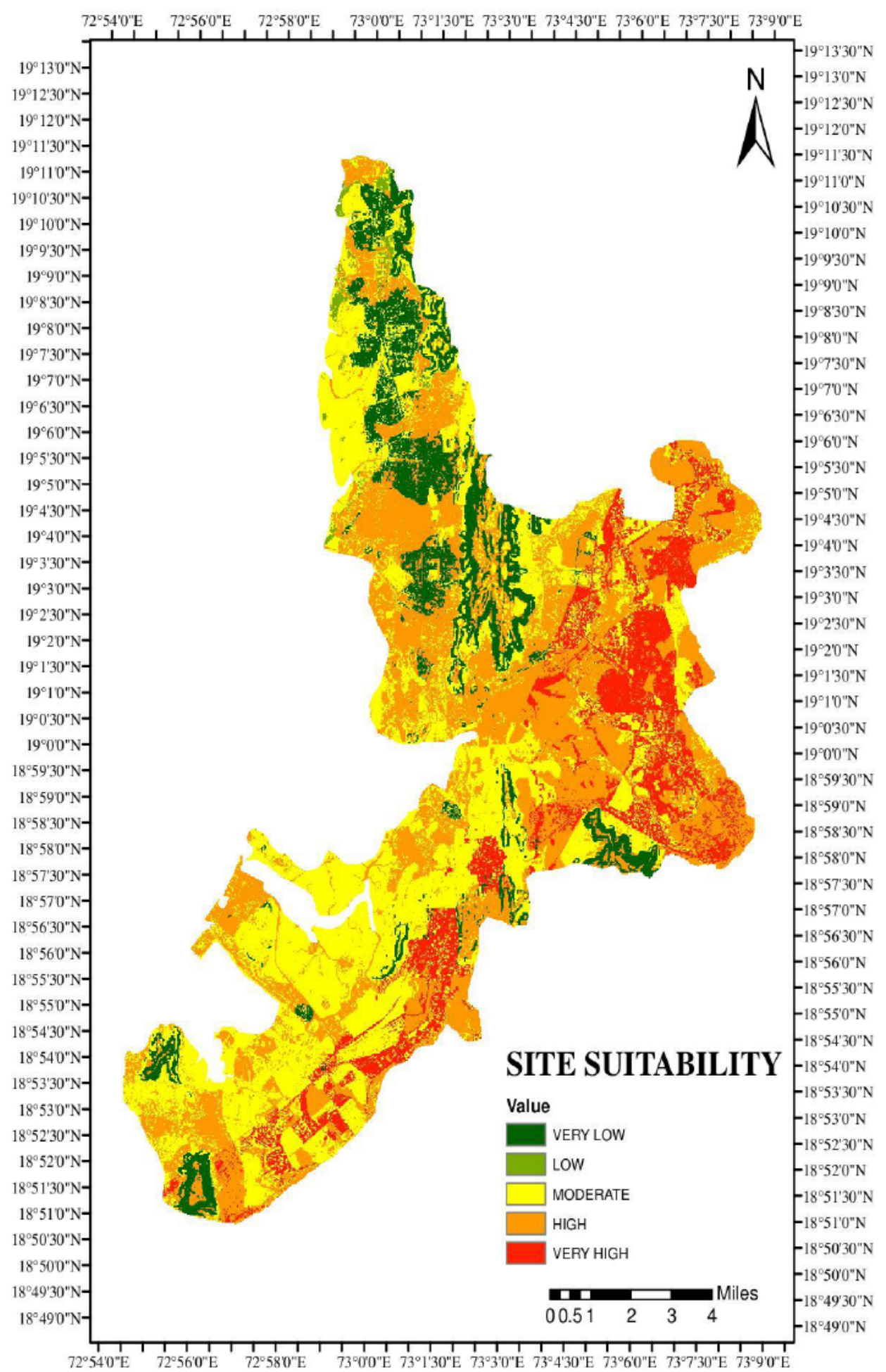

Figure 4 Site Suitability Map

\section{CONCLUSION}

In this GIS base, study multicriteria evaluation technique and weightage overlay process is used which is very simple and flexible, for finding various suitability categories in Navi Mumbai. It provides a full and satisfactory database of availability of suitable land for development work and it helps in solving any specific problem. Integrating environmental dimensions into land 
management practices in urban areas from the preferably stage of the design method will greatly contribute to the longer-term sustainability of urban region. Based on the result the final map is classified into five categories very low $\left(38.83 \mathrm{~km}^{2}\right)$, low $\left(2.24 \mathrm{~km}^{2}\right)$, moderately $\left(127.62 \mathrm{~km}^{2}\right)$, high $\left(129.34 \mathrm{~km}^{2}\right)$ and very high $\left(41.29 \mathrm{~km}^{2}\right)$. The theoretical methodology implemented in the present study will help to locate a suitable site for land development in other parts of the world. The result of the study will help the local people as well as planners to frame and implement a suitable master plan for the development of the urban region. Taking of any final decision for any area extra filed investigation required.

\section{REFERENCES}

[1] Thurstone, L. L. A Law of Comparative Judgements. Psychological Reviews, 34, 1927 pp. 273286.

[2] Davis K. The Origin and Growth of Urbanization in the World Am J Sociol 60, 1955 pp. 429437.

[3] B. Ramyaa Sree and SS. Asadi A Remote Sensing and GIS Based Critical Evaluation of Change Detection Study in Thimmaipally Watershed for Land Resources Management, International Journal of Civil Engineering and Technology, 8(4), 2017, pp. 2110-2124

[4] Saaty, T. L. The analytic hierarchy processes. New York: McGraw-Hill (1980).

[5] Jain, K. and Subbaiah, V. Site Suitability Analysis for Urban Development Using GIS. Journal of Applied Science, 2007 pp. 2576-2583.

[6] Santhosh Ram, A Study on Variations in Water Productivity by Using Gis Based Epic Model, International Journal of Civil Engineering and Technology (IJCIET), Volume 5, Issue 3, March (2014), pp. 151-159

[7] Rawat, J. S. Database Management System for Knuigard Watershed, Kumaun Lesser Himalaya, Uttarakhand, India. Current Science, 98(10) 2010 pp. 1340-1348.

[8] Elaalem, M. Comberm, A. and Fisher P. A Comparison of Fuzzy AHP and Ideal Point Method for Evaluating Land Suitability. Transaction in GIS, 15(3) 2011 pp. 329-346.

[9] Manish Kumar and Vasim Riyasat Shaikh Site Suitability Analysis for Urban Development Using GIS Based Multicriteria Evaluation Technique: A Case Study of Municipal Area Dehradun District, Uttarakhand, India Journal of Indian Society of Remote Sensing 41(2) 2013 pp. 417-424.

[10] G.S.Sarma, SS. Asadi and S.Lakshmi Narayana, Creation of Remote Sensing \& GIS Based Land Resources Information System For Land Resources Management. International Journal of Civil Engineering and Technology, 8(8), 2017, pp. 1738-1746.

[11] Santosh Kumar and Ritesh Kumar. Site Suitability Analysis For Urban Development of a Hill Town Using GIS Based Multicriteria Evaluation Technique: A Case Study of Nahan Town, Himachal Pradesh, India. International Journal of Advance Remote Sensing and GIS, 2014, pp. 516-524.

[12] N. Vaani and P. Porchelvan. GIS Based Agricultural Drought Assessment for the State of Tamilnadu, India Using Vegetation Condition Index (VCI). International Journal of Civil Engineering and Technology, 8(5), 2017, pp. 1185-1194

[13] Saaty, T. L. Fundamentals of Decision Making and Priority Theory with the Analytical Hierarchy Process. 1994, Pittsburgh: RWS Publications.

[14] Malczewski, J. Criteria Weighting Using GIS and Multicriteria Decision Analysis. 7(18). 1999 pp. 182-187.

[15] SS. Asadi, Abel Dungana and Paras Mani Ghalley, Remote Sensing and Gis Based Critical Evalution of Water Balance Study from Woochu Watershed, Bhutan, International Journal of Mechanical Engineering and Technology 8(10), 2017, pp. 434-447

[16] Ian Heywood, Sarah Cornelius, Steve Carver, and Srinivasa Raju An Introduction to Geographical Information Systems. Second Edition, Pearson, 2006 pp. 2-14. 